\title{
Comments
}

\section{EXONERATING THE SURETY: IMPLICATIONS OF THE CALIFORNIA ANTIDEFICIENCY SCHEME}

A bank makes a loan for the purpose of enabling the borrower to finance improvement of his property. The borrower signs a note for the amount advanced, and, as security for the loan, he gives the bank a first deed of trust on the property to be improved. As a condition to making the loan, the bank requests that a third party agree to guarantee it. In compliance with the bank's request, the borrower's general contractor guarantees payment of the debt by executing a written guarantee of performance of the principal obligation. Both the borrower and the surety ${ }^{1}$ sign a building loan agreement providing for the exclusive use of the money loaned in financing improvement of the property. ${ }^{2}$ The borrower, or principal debtor, subsequently fails to make payment on the note by the maturity date.

In California, a bank or other lender occupying the position of the creditor described above has certain statutory remedies when the principal debtor defaults. A secured ${ }^{3}$ creditor with a power of sale can choose one of two alternative methods of realizing on the security. ${ }^{4} \mathrm{He}$ may bring suit to foreclose judicially, ${ }^{5}$ or he can exercise his power of sale, after complying with statutory requirements, ${ }^{6}$ and foreclose

1. "A surety or guarantor is one who promises to answer for the debt, default, or miscarriage of another, or hypothecates property as security therefor." CAL. CIV. CODE $\$ 2787$ (West 1954). "The legislature in 1939 abolished all distinction between sureties and guarantors ...." Ingalls v. Bell, 43 Cal. App. 2d 356, 365, 110 P.2d 1068, 1074 (1941). "A continuing guarantec is now a form of suretyship obligation and is subject to all provisions of law relating to suretyship." American Guar. Corp. v. Stoody, 230 Cal. App. 2d 390, 392, 4 I Cal. Rptr. 69, 70 (1964); Hill \& Morton, 1nc. v. Coughlan, 214 Cal. App. 2d 545, 548, 29 Cal. Rptr. 550, 552 (1963).

2. This agreement prevents the debt from becoming a purchase money obligation by insuring that the loan will not be used to acquire the property. For the result in the purchase money situation see text accompanying notes 97-102 infra. The foregoing fact situation corresponds to that in Union Bank v. Gradsky, 265 A.C.A. 48, 71 Cal. Rptr. 64 (1968), discussed in text accompanying notes 3437 infra.

3. Transactions characterized as secured are those in which a person who is obligated on a debt instrument pledges an interest in property to insure satisfaction of his obligation. This article is concerned with obligations governed by the California antideficiency legislation, sec statutes cited in note 7 infra, i.c., obligations for which the debtor hypothecates real property as security.

4. "Foreclosure by action [judicial foreclosurel and sale under the power [nonjudicial foreclosure] are concurrent remedies for both the deed of trust and the mortgage with a power of sale." Hetland, Real Estate Sales Transactions 78 (1966) (syllabus distributed by California Continuing Education of the Bar). A surety may compel the creditor to exhaust the security before seeking recovery on the guaranty. American Guar. Corp. v. Stoody, 230 Cal. App. 2d 390, 41 Cal. Rptr. 69 (1964).

5. Cal. Civ. Pro. Code $\S \S 725 a, 727-30$ (West 1955); id. § 726 (West Supp. 1967).

6. "[l]n order for a lender to realize upon his security through the exercise of a power of sale contained in his deed of trust, he must record a notice of default, and three months must elapse after the recordation before a notice of sale is published or posted. (Civ. Code § 2924.)" Smith v. Allen, 
nonjudicially. Under either method, the creditor may find that a considerable sum remains unpaid on the note and seek to recover it from the surety. The California antideficiency legislation ${ }^{7}$ governs the rights and remedies available to the creditor and principal obligor following judicial and nonjudicial foreclosure, but makes no express provision for the surety or guarantor. The deficiency prohibition of California Code of Civil Procedure section 580d expresses the most significant distinction between the two enforcement methods. Whereas the borrower remains liable for a deficicncy after judicial sale, section 580d releases the principal debtor from liability for a personal judgment following nonjudicial sale:

No judgment shall be rendered for any deficiency upon a note secured by a deed of trust or mortgage upon real property hereafter executed in any case in which the real property has been sold by the mortgagee or trustee under power of sale contained in such mortgage or deed of trust. ${ }^{8}$

The statute directly protects the principal obligor, and hence indirectly affects the surety's continued liability. This Comment discusses the question of whether the creditor may compel the surety to pay the deficit remaining on the note after application of the nonjudicial sale proceeds to the debt, or whether the creditor, by "electing to pursue a [nonjudicial] remedy which destroys both the security and the possibility of the surety's reimbursement from the principal debtor," is estopped from resorting to the surety for recovery of a personal judgment. ${ }^{9}$ The courts and legal profession in California have begun to recognize that a secured non-purchase money creditor who provides the principal with antideficiency protection by foreclosing nonjudicially has exonerated the surety. ${ }^{10}$ The following discussion will focus on the reasoning underlying the surety's release. Part 1 will propose the surety's exoneration as a result of his loss of rights against the principal debtor. Part II considers the surety's defense in light of the statutory intent of the antideficiency legislation.

68 A.C. 91, 94, 436 P.2d 65, 67, 65 Cal. Rptr. 153, 155 (1968). Notice must be given twenty days before the date of sale and other requirements must be complied with. CAL. Civ. Pro. Code $\S 692$ (West Supp. 1967); id. $\S 694$ (West 1955); CAL. Civ. CoDE $\S 2924 b$ (West Supp. 1967).

7. Cal. Civ. Pro. Code $\$ \S 580$ a, 580d (West 1955); id. $\$ \S 580$ b. 726 (West Supp. 1967).

8. Cal. Civ. Pro. Code $\S 580$ d (West 1955) (reproduced in part).

9. This is the holding in Union Bank v. Gradsky, 265 A.C.A. 48, 55, 71 Cal. Rptr. 64, 69 (1968).

10. Professor John R. Hetland suggested this result in Hetland, supra note 4, at 95-96. 


\section{THE EXONERATION ARGUMENT}

\section{A. The Creditor Releases the Surety by Prejudicing His Rights}

A material alteration ${ }^{11}$ of the contract governing the principal obligation discharges a surety where substantial rights of the parties thereto are changed, whether such alteration increases or decreases the obligation, ${ }^{12}$ or is otherwise prejudicial or beneficial to the surety. ${ }^{13}$ The California statutory scheme discussed below codified this principle. The surety's interests are not abandoned to the creditor's mercy; California Civil Code section $2819^{14}$ expressly prohibits the creditor, on pain of exonerating the surety, from relinquishing any rights against the principal debtor unless he does so with the surety's consent. Civil Code sections $2845^{15}$ and $2849^{16}$ afford the surety the benefit of the creditor's remedies and the security he possesses to insure performance of the principal obligation. ${ }^{17}$ Section 2849 , according to Massachusetts Bonding and Insurance Company v. Osborne, ${ }^{18}$ must be construed as preventing the creditor from recovering from the surety after renouncing his right to pursue the principal obligor. The creditor's release of the principal terminates the surety's liability where the latter has not

11. "A material alteration is one that works some change in the rights, interests, or obligations of the parties to the writing." Lasky v. Bew, 22 Cal. App. 393, 396, 134 P. 358, 360 (1913).

12. Boteler v. Conway, 13 Cal. App. 2d 79, 82, 56 P.2d 587, 589 (1936).

13. Verdugo Highlands, Inc. v. Security Ins. Co., 240 Cal. App. 2d 527, 530, 49 Cal. Rptr. 736, 739 (1966); Ralston-Purina Co. v. Carter, 210 Cal. App. 2d 372, 378, 26 Cal. Rptr. 690, 694 (1962); McMannus v. Temple Estate Co., 10 Cal. App. 2d 419, 421-22, 51 P.2d 1124, 1125 (1935): the court is "not permitted to speculate whether the alteration benefits or injures the guarantor. $1 \mathrm{t}$ is enough that it is a material alteration of the terms of the guaranty." First Congregational Church of Christ v. Lowrey, 175 Cal. 124, 126, 165 P. 440, 441 (1917).

14. CAL. Civ. Code $\S 2819$ (West 1954): "A surety is exonerated, except so far as he may be indemnified by the principal, if by any act of the creditor, without the consent of the surety, the original obligation of the principal is altered in any respect, or the remedies or rights of the creditor against the principal, in respect thereto, in any way impaired or suspended."

15. CAL. CIV. CODE $\S 2845$ (West 1954): "A surety may require his creditor to proceed against the principal, or to pursue any other remedy in his power which the surety can not himself pursue, and which would lighten his burden; and if in such case the creditor neglects to do so, the surety is exonerated to the extent to which he is thereby prejudiced."

16. CAL. CIV. CODE $\S 2849$ (West 1954): "A surety is entitled to the benefit of every security for the performance of the prineipal obligation held by the creditor, or by a co-surety . . . whether the surety was aware of the security or not."

17. Ingalls v. Bell, 43 Cal. App. 2d 356, 365, 110 P.2d 1068, 1074 (1941) (section 2845); Massachusetts Bonding \& Ins. Co. v. Osborne, 233 Cal. App. 2d 648, 663, 43 Cal. Rptr. 761, 770 (1965): "This section [Civ. Code section 2849] appears to impose upon a creditor the obligation not to release to the prejudice of the indemnitor, any property which comes under its control and which can be used to satisfy the liability of the surety . . . .

18. 233 Cal. App. 2d 648, 661, 43 Cal. Rptr. 761, 770 (1965). 
consented to such release. ${ }^{19}$ When a creditor who has two alternative means of realizing on the security ${ }^{20}$ chooses to foreclose in a nonjudicial proceeding, the surety can argue that the creditor has materially altered the original obligation and prejudiced the surety's interests by defeating his right to recover from the principal debtor. By determining to sell privately rather than to foreclose judicially, the creditor has invoked the section $580 \mathrm{~d}$ bar to his own further recovery from the principal, thereby extinguishing any right of action to which the surety could have been subrogated. This prejudicial alteration of the original obligation releases the surety from liability.

- Under a theory of subrogation ${ }^{21}$ a surety who satisfies a debt incurred by a principal is automatically subrogated to the creditor's rights against the primary obligor. ${ }^{22}$

One who is neither an intermeddler nor a volunteer and who pays the obligation of another, for which the other is primarily liable, is equitably subrogated to all of the rights and to the security formerly held by the obligee against the principal obligor. ${ }^{23}$

In Patent Scaffolding Company v. William Simpson Construction Company, ${ }^{24}$ the court held that "[n]o express assignment of the [creditor's] cause of action is required; equitable subrogation is accomplished by operation of law." ${ }^{25}$ Civil Code section 2848 reflects legislative adoption of the subrogation theory in California. ${ }^{26}$ It provides that a surety who has satisfied the principal's obligation "is entitled to enforce every remedy which the creditor then has against the principal to the extent of reimbursing what he has expended . . . ." "27

A California surety who enters into an agreement to guaranty a secured debt may reasonably rely on the protection that the subrogation

19. Bloom v. Bender, 48 Cal. 2d 793, 313 P.2d 568 (1967); Goatman v. Pacific Ready-Cut Homes Inc., 112 Cal. App. 397, 402, 297 P. 68, 70-71 (1931).

20. See discussion accompanying notes 4-6 supra.

21. The subrogation theory has not gone unchallenged. See Berrington v. Williams, $244 \mathrm{Cal}$. App. 2d 130, 52 Cal. Rptr. 772 (1966), discussed in text accompanying notes 67-71 infra.

22. Durgin v. Kaplan, 68 A.C. 79, 82, 65 Cal. Rptr. 158, 160 (1968); De Cruz v. Reid, 258 A.C.A. 367, 373, 65 Cal. Rptr. 698, 701 (1968); Ingalls v. Bell, 43 Cal. App. 2d 356, 367, 110 P.2d 1068,1075 (1941) ("[1]t is not a condition precedent to recovery upon a guaranty that the creditor assign all his rights against the debtor over to the guarantor").

23. Union Bank v. Gradsky, 265 A.C.A. 48, 52-53, 71 Cal. Rptr. 64, 68 (1968).

24. 256 Cal. App. 2d 506, 64 Cal. Rptr. 187 (1967).

25. Id. at 510, 64 Cal. Rptr. at 190.

26. CAL. CIV. Code $\S 2849$ (West 1954) should be read in conjunction with section 2848 as it amplifies California subrogation procedure by affording the surety "the benefit of every security for the performance of the principal obligation held by the creditor ...." Id.

27. CaL. Civ. Code $\$ 2848$ (West 1954). 
procedure affords him. When a creditor forecloses his security interest at nonjudicial sale, however, he nullifies the surety's subrogation right. By opting in favor of the nonjudicial remedy, the creditor enables the principal debtor to assert the deficiency prohibition of section $580 \mathrm{~d}$ as a defense to the surety's action for reimbursement. The creditor's actions have shielded the principal from personal liability to the surety. ${ }^{28}$ Because this is clearly a substantial and prejudicial alteration of the surety's rights with respect to the principal obligation, it should exonerate him from further liability.

At least two California courts of appeal have adopted this reasoning. In Massachusetts Bonding and Insurance Conıany v. Osborne, ${ }^{29}$ the creditor's ${ }^{30}$ actions relieved a general partner of the debtor partnership from personal liability. The court held that the creditor had discharged one of the indemnitors by prejudicing her right to reimbursement from the principal." The trial court reasoned that the indemnitors "have an equitable right over and against the principal to recover any loss that they may suffer due to the agreement of indemnity." 32 Thus, any action by the creditor that impaired or prejudiced those rights discharged them. The court of appeal affirmed, citing Civil Code section 2849 for the proposition that whatever benefit

28. Discussing the possibility that a guarantor could assert the obligation in an action against the principal, Professor Hetland concludes that "such a possibility does not cxist. The courts consistently strike down schemes aimed at avoiding the deficiency legislation by illusory changes in form. A flimsy avoidance device based upon an intermediatc surety would have no chance of success." Hetland, Deficiency Judgment Limitations in California-A New Judicial Approach, 51 CALIF. L. Rev. 1, 25-26 \& n.113 (1963). The reference in Union Bank v. Gradsky; 265 A.C.A. 48, $55 \mathrm{n} .8,71$ Cal. Rptr. $64,69-70 \mathrm{n} .8$ (1968), to Hetland's lack of authority for the above statement, which is reproduced in Gradsky without the pertinent footnote, is hard to understand in view of the four cases Hetland cites as examples of unsuccessful avoidance devices. Judging from the languagc of the opinion, Gradsky's oblique doubt about Hetland's premise is obviously not onc which even the court would take seriously if confronted with the relevant fact situation. The court asserts that, "To permit a guarantor to recover reimbursement from the debtor would permit circumvention of the legislative purpose in enacting section 580d." The result would "permit the recovery of a deficiency judgment against the debtor following a nonjudicial sale of the security under a different labcl. it makes no difference to [the principal's] purse whether the recovery is by the original creditor in a direct action following nonjudicial sale of the security, or whether the recovery is in an action by the guarantor for reimbursement of the same sum." Id. at 54,71 Cal. Rptr. at 69 . In vicw of this language it secms clear that the Gradsky court agrees with Hetland's assertion that a change in form so as to avoid the deficiency prohibition can only be "illusory."

29. 233 Cal. App. 2d 648, 43 Cal. Rptr. 761 (1965).

30. In the interest of simplicity, the term "crcditor" is used here to rcfer to the plaintiff Mass. Bonding \& Ins. Co., which became a creditor, vis a vis the indemnitors who were its sureties, by satisfying its obligations under certain bonds issued for the benefit of the principal partnership.

31. $233 \mathrm{Cal}$. App. $2 \mathrm{~d}$ at $661,43 \mathrm{Cal}$. Rptr. at 769. The other indemnitor involved was a partner in the principal partnership, and therefore was not adversely affected by the creditor's promise not to execute. $I d$.

32. 233 Cal. App. $2 d$ at 658,43 Cal. Rptr. at 767. 
is enjoyed by the creditor must also accrue to the indemnitors-particularly, "the right to pursue the individual partners for reimbursement. ${ }^{\prime 33}$

In Union Bank v. Gradsky $y^{34}$ another California court of appeal applied the Massachusetts Bonding reasoning to the problem discussed in this Comment. Terming the question one "of first impression in California," 35 the court in Gradsky concluded that a creditor who foreclosed nonjudicially exonerated the surety by depriving him of a right to reimbursement from the principal..$^{36}$ The court reasoned that the creditor, by his decision whether or not to exercise his right to a personal judgment against the principal, has the power to preserve or destroy the rights available to the surety through subrogation. Consequently " $[t]$ he creditor has a duty to the surety not to impair the surety's remedies against the principal debtor." ${ }^{37}$ On these grounds Gradsky concluded that a creditor who prejudices a surety's interests by his choice of remedy is estopped from recovering from him.

\section{B. Possible Problems in the Operation of the Exoneration Theory}

\section{l. Implied Consent: An Obstacle to the Prejudice Theory?}

The creditor's prejudicial acts do not exonerate the surety if the surety has consented to those acts. ${ }^{38}$ The Supreme Court of California, in Bloom v. Bender, ${ }^{39}$ affirmed the rule that "where the surety consents to an alteration of the original obligation of the principal, or the impairment or suspension of any of the creditor's rights or remedies against the principal, the surety is not exonerated." ${ }^{\prime 40}$

One objection to the surety's release, in view of the Bloom holding is that his consent to the creditor's nonjudicial sale may be viewed as

33. Id. at 661,43 Cal. Rptr. at 770 .

34. 265 A.C.A. 48,71 Cal. Rptr. 64 (1968).

35. Id. at $49,71 \mathrm{Cal}$. Rptr. at 65 . In a later case focusing on the same question the California Court of Appeal for the Fourth District expressly approved the Gradsky holding. See Union Bank v. Brummell __ ACA _ 75 Cal. Rptr. 234 (1969).

36. In Gradsky both the principal (Bess) and the guarantor (Max) had the same last name. The court noted, however, that there was no showing that they were related by blood or marriage, and held that Max was therefore a "true" guarantor as distinguished from one who is actually a principal obligor whose liability cannot be altered by the execution of a guaranty. 265 A.C.A. 48 , 50, 71 Cal. Rptr. 64, 66. For a discussion of the result where the latter fact situation obtains see Union Bank v. Dorn, 254 Cal. App. 2d 157,61 Cal. Rptr. 893 (1967), holding that assumption of liability as a guarantor adds nothing to the primary liability of the principal obligor under section 580d. See Valinda Builders, Inc. v. Bissner, 230 Cal. App. 2d 106; 40 Eat. Rptr. 735 (1964) and Riddle v. Lushing, 203 Cal. App. 2d 831, 2 I Caí. Rptr. 902 (1962), upholding a similar result under section 580b, and Everts v. Matteson, 2I Cal. 2d 437, 132 P.2d 476 (1942) for the result under section 580a (all cited in Gradsky, supra at $50 \mathrm{n} .2,71 \mathrm{Cal}$. Rptr. at $66 \mathrm{n} .2$ ).

37. Union Bank v. Gradsky, 265 A.C.A. 48, 55, 7 I Cal. Rptr. 64, 69 (I968).

38. See CAL. Civ. Code $\S 2819$ (West 1954) supra note 14.

39. 48 Cal. 2d 793, 313 P.2d 568 (1957).

40. Id. at 800,313 P.2d at 572 . 
implicit in the agreement to guarantee an obligation secured by a deed of trust. If the surety has consented to the principal's release after the creditor's nonjudicial sale he is not relieved of liability. The surety's presumed consent is based on his undertaking a suretyship obligation with knowledge of the creditor's power of sale. 1t might be argued that knowledge of the power should have put the surety on notice that the creditor could foreclose his security interest at a private sale, thereby providing the principal with a section $580 \mathrm{~d}$ defense to personal liability and defeating the surety's subrogation right. By entering into the suretyship agreement, the argument continues, the surety has impliedly consented to remain liable despite the creditor's subsequent release of the principal through nonjudicial foreclosure. However, three California supreme court cases spanning almost a fifty year period suggest that implied consent is not sufficient to support the surety's continued liability following private sale.

In Bloom v. Bender ${ }^{41}$ the court held that the creditor's release of the principal did not exonerate the guarantor where the latter expressly consented to such release. ${ }^{42}$ The guaranty agreement provided that " $[t]$ he liability hereby assumed shall not be affected by ... . [the creditor's] ... acceptance of any settlement or composition offered by" the principal ${ }^{43}$ The court found that the provision reflected the parties' intention to avoid releasing the guarantor. ${ }^{44}$ In the section $580 \mathrm{~d}$ context the question is whether the surety's entry into the suretyship agreement with knowledge of the creditor's power of sale demonstrates awareness and acceptance of continued liability to the extent found in Bloom. The express consent to the principal's release revealed by the guaranty agreement in Bloom is very different from the implied consent which might be imputed to a surety who assumes liability knowing only of the creditor's power of sale.

An earlier California supreme court adopted a similarly narrow construction of consent in Michelin Tire Company v. Bentel. ${ }^{45}$ There the court held that defendants were not liable on their surety agreement although one of them had consented to the change which exonerated them. ${ }^{46}$ The sureties promised to pay any judgment recovered by the creditor in an action pending against the principal, should the principal default. The defendants in the pending action agreed with the other
41. 48 Cal. 2d 793, 313 P.2d 568 (1957).
42. Id. at 800,313 P.2d at 572 .
43. Id. at 796,313 P.2d at 570 .
44. Id. at 803,313 P.2d at 574 .
45. 184 Cal. 315, 193 P. 770 (1920).
46. Id. at 323,193 P. at 773-74. 
parties to the suit that they would not oppose the continuation of the action based on an amended complaint. ${ }^{47}$ In the creditor's subsequent action against the sureties, the court held that the sureties were not liable because they had not assumed liability for the new cause of action. One of the sureties, a defendant in the creditor's prior suit against the principal, was held to have consented to the amended complaint, ${ }^{48}$ but the court concluded that this consent did not extend the original undertaking to the new cause of action. The court observed that the consenting surety's "consent as a party to continue the action upon the newly alleged cause of action is not equivalent to an agreement by him that his original undertaking covering the old debt should be altered so as to cover the different debt set up in the amended complaint." 49

The court's reasoning-that merely by consenting to the amended complaint, the surety does not necessarily extend his liability beyond the claim comprehended by the original agreement-is equally applicable to the situation where the creditor chooses nonjudicial sale. The surety has consented to the creditor's use of the power of sale, but not to continued liability following nonjudicial foreclosure..$^{50}$ The judiciary's willingness to read consent narrowly and construe the surety's reasonable expectations in a protective light supports this argument.

In U.S. Leasing Corporation v. duPont ${ }^{51}$ the 1968 court used a similarly strict standard to determine whether the surety had consented to an alteration of the original obligation. Plaintiff lessor sued to enforce the defendants' guaranty of the lessee's performance of the terms of a lease. The guaranty provided in part:

The liability of the undersigned Guarantors hereunder shall not exceed at any one time the total sum of $\$ 135,120.00$. Notwithstanding the foregoing limitation, Lessor may permit the total amount of Lessee's indebtedness and obligations to Lessor to exceed the Guarantors' aforesaid maximum liability hereunder. ${ }^{32}$

The issue was whether the sureties had assumed responsibility for a

47. During pendency of the attachment suit, plaintiff corporation discovered that it was not the creditor having the right of action, but only an agent of such creditor, and subsequently obtained an assignment of all claims against the principal debtor. The assigned claims became the basis of the amended complaint. $I d$. at 319,193 P. at 772.

48. His attorney had signed the stipulation agreeing to the changed cause of action. Id. at 323,193 P. at 774.

49. Id.

50. Such consent could serve the purpose of preventing exoneration of the surety where the creditor began proceedings to sell under the power and subsequently decided to foreclose judicially.

51. 69 A.C. 279,444 P.2d 65, 70 Cal. Rptr. 393 (1968).

52. Id. at 283 n.3, 444 P.2d at 67-68 n.3, 70 Cal. Rptr. at 395-96 n.3. 
subsequent alteration of the lessee's obligation exceeding the contract maximum. In construing the agreement the court concluded that " $[t]$ he guaranty provision permitting [the creditor] to increase the amount of [the principal's] indebtedness above defendants' maximum liability did not further provide that such increases would be encompassed within the guaranty." "In effect, the guarantors had agreed to remain liable under the original agreement despite subsequent increases in the lessee's indebtedness, which could otherwise have exonerated them. However, the court held that not only had they not assumed responsibility for any additional liability, but that the transformation of the obligation from a lease to a purchase agreement constituted "such a fundamental and radical change in the nature of [the principal's] obligation" that it exceeded the bounds of permissable modification..$^{54}$

Before finding that a surety has consented to remain liable despite changes in the original obligation the courts require that his consent be explicit. The standard is stated in Michelin:

In order to make [the surety] liable on the original undertaking for a judgment on the new cause of action, his consent must have been given under such circumstances, or must have been couched in such terms, as to manifest his intent that the original undertaking should stand as security for the newly alleged debt; it must be the equivalent of a new contract by him as surety for such new debt; it must be in effect a consent to the alteration of his contract as surety to conform to the new conditions..$^{\text {ss }}$

Judicial reluctance to construe consent adversely to the surety is clearly reflected in the language of the cases. The Arizona supreme court has held that a guarantor who consented to forebearance by a creditor did not waive the defense that the creditor's failure to preserve the security prejudiced his subrogation right: "[i]f the destruction or impairment of such a [subrogation] right is to be waived by a guarantor, it should only be by the most unequivocal language in the guaranty agreement." 56

The Michelin and duPont reasoning, expressing a policy against a liberal interpretation of implied consent, should control in determining whether a surety has implicitly consented to remain liable after nonjudicial sale. Union Bank v. Gradsky, ${ }^{57}$ the first 580d case to reach the consent issue, concluded that, in the absence of language in the

\footnotetext{
53. Id. at 294,444 P.2d at 74, 70 Cal. Rptr. at 402 .

54. Id. at 297,444 P.2d at 76, 70 Cal. Rptr. at 404.

55. 184 Cal. 315, 324, 193 P. 770,774 (1920).

56. D.W. Jaquays \& Co. v. First Security Bank, 101 Ariz. 301, 305, 419 P.2d 85, 89 (1966).

57. 265 A.C.A. 48,7 i Cal. Rptr. 64 (1968).
} 
guarantee agreement which "specifically waive[d]" the guarantor's defense, it was undesirable "to strain the instrument to find that waiver by implication." 58 This judicial stance appears to reflect approval of the surety's publicly useful function and a desire to encourage its continuation. ${ }^{59}$ The courts should not adopt a constructive notice rationale to impose liability on a surety. Rather than employing an implied consent doctrine to determine whether the surety remains liable after nonjudicial sale, the courts should require unequivocal proof of the surety's intention to remain bound after loss of his right to reimbursement. ${ }^{60}$

\section{The Surety is Not Exonerated Following Nonjudicial Sale if the Principal Already Has a Section $580 b$ Defense}

Section 580b of the California Code of Civil Procedure prohibits a deficiency judgment after any sale, private or judicial, of real property for nonpayment of a debt constituting a "purchase money" obligation within the scope of the statute. ${ }^{61}$ ln contrast, section $580 \mathrm{~d}$ only bars a

58. Id. at 56,71 Cal. Rptr. at 70. The court does suggest, however, that the guarantor is free to waive, by express contractual provision, his right to object to the creditor's recovery following nonjudicial sale. The court bases this conclusion on the contention that the guarantor's rights do not derive from a direct application of section 580d's antideficiency protection to the guarantor-a question discussed in Part 11 , infra-and are therefore subject to waiver. Id. This outcome seems questionable, if only on policy grounds, since it enables creditors to obtain an advantage over guarantors by means of institutionally devised instruments which the courts refused to allow when asked to do so on implied consent grounds. The consent obtained by means of form documents does not seem inherently more compelling or meaningful than that which the courts refused to draw from the fact of the surety's entry into the guaranty agreement with knowledge of the creditor's power of sale.

59. Most sureties in the litigated cases appear to be persons acting in their individual capacities rather than insurance companies or other institutional entities, and this fact should invoke a more protective attitude on the part of the courts. On the identity of sureties see Engelman v. Gordon, 242 Cal. App. 2d 510, 51 Cal. Rptr. 627 (1966) (guarantor was sole stockholder of the principal corporation); Lange v. Aver, 241 Cal. App. 2d 793, 50 Cal. Rptr. 847 (1966) (guarantors were individual endorsers); Mass. Bonding \& Ins. Co. v. Osborne, 233 Cal. App. 2d 648, 43 Cal. Rptr. 761 (1965) (guarantors were individual indemnitors); American Guar. Corp. v. Stoody, 230 Cal. App. 2d 390, 41 Cal. Rptr. 69 (1964) (guarantor was an individual); Heckes v. Sapp, 229 Cal. App. 2d 549, 40 Cal. Rptr. 485 (1964) (guarantors were sole shareholders of the principal obligor corporation); Katz v. Haskell, 196 Cal. App. 2d 144, 16 Cal. Rptr. 453 (1961) (guarantor was individual assignor of a purchase money note); Stephenson v. Lawn, 155 Cal. App. 2d 669, 318 P.2d 132 (1957) (guarantors were individual endorsers); Security-First Nat'l Bank v. Chapman, 41 Cal. App. 2d 219, 106 P.2d 431 (1940) (guarantor was an individual with the same name as the principal corporation).

60. Since "[a] waiver is defined as the intentional relinquishment of a known right," De Cruz v. Reid, 258 A.C.A. 367, 373, 65 Cal. Rptr. 698, 70 I (1968), it does not seem unreasonable for the courts to require something more than mere entry into the suretyship agreement as demonstrative of such a waiver.

61. "Section $580 \mathrm{~b}$ places the full risk of inadequate security on the purchase money mortgagee." Roseleaf Corp. v. Chierighino, 59 Cal. 2d 35, 42, 378 P.2d 97, 101, 27 Cal. Rptr. 873, 877 (1963); see American Sav. \& Loan Ass'n v. Leeds, 68 A.C. 637, 641, 440 P.2d 933, 937, 68 Cal. Rptr. 453, 457 (1968). 
deficiency after nonjudicial sale, and the prohibition is not limited to purchase money obligations. In the section $580 \mathrm{~b}$ purchase money context, as under section $580 \mathrm{~d}$, the deficiency prohibition releases the principal from personal liability. Where section $580 \mathrm{~b}$ governs, however, the surety remains liable despite the principal's release. ${ }^{62}$ But this result should not compel similar guarantor liability in the section 580d, nonpurchase money context.

Where section $580 \mathrm{~b}$ applies, the creditor, by foreclosing to collect on a debt incurred to purchase the property, merely activates an already existing deficiency prohibition. ${ }^{63}$ In section 580 b's purchase money context the surety never had any right to reimbursement; ${ }^{64}$ the character of the obligation itself precludes the surety from recovering from the principal. Therefore, the purehase money creditor has not prejudiced the surety's position by foreclosing nonjudicially. In contrast, in the section $580 \mathrm{~d}$ non-purchase money situation, the creditor who chooses private sale has prejudiced the surety's right to reimbursement from the principal. The creditor, by his own action in electing nonjudicial foreclosure, has invoked the section $580 \mathrm{~d}$ bar, releasing the principal from personal liability. ${ }^{65}$

\section{The Separate Contract Theory}

The surety bases his claim for exoneration on loss of his subrogation right against the principal. The creditor's nonjudicial sale relieves the principal of personal liability under section $580 \mathrm{~d}$, thereby nullifying any right of recovery that otherwise could have passed to the surety by subrogation. ${ }^{66}$ However, the California court of appeal in

62. Heckes v. Sapp, 229 Cal. App. 2d 549, 40 Cal. Rptr. 485 (1964); Hetland, supra note 28, at $23-28$.

63. "[F]rom the inception of the transaction section $580 \mathrm{~b}$ left the foreclosing creditor no recovery other than the security." Hetland, supra note 28 , at $31 \mathrm{n} .143$.

64. When entering into the agreement, "[t] he surety would know of the debtor's $580 \mathrm{~b}$ defense in the same sense that he would know of the debtor's right to rely upon the statute of limitations, or upon any other statutory defense." Hetland, supra note 28 , at 26 . For an example of the same notice analysis applied to a different fact situation see Steiner Lumber Co., Inc. v. Stegge, 201 Cal. App. 2d 646, 20 Cal. Rptr. 335 (1962). There the court held that the creditor's waiver of security did not discharge the surety where the creditor had already "agreed not to assert its lien rights" in the same contract which bound the sureties. Id. at 649, 20 Cal. Rptr. at 337.

65. The court in Lange v. Aver, 241 Cal. App. 2d 793, 50 Cal. Rptr. 847 (1966) used similar reasoning to distinguish the immunity from liability which section $580 \mathrm{~b}$ confers on the principal from a "discharge" as contemplated by CAL. Civ. CoDE $\S 3201$ (West 1954). Under section 3201 the discharge of a prior party discharges the person secondarily liable. The court in Lange, supra, held that, "Discharge in this context implies the extinguishment, cancellation, or removal of a previously existing liability" while, "From the inception of such ... [a section 580b purchase money] obligation the obligor is immune from liability thereon." Id. at 799, 50 Cal. Rptr. at 851.

66. See text accompanying notes 21-28 supra. 
Berrington $v$. Williams ${ }^{67}$ held that the surety's right to reimbursement derives from a separate contract implied in law between the surety and the principal. Under this separate contract theory, the surety retains a right to recover from the principal following nonjudicial foreclosure; therefore, he is not prejudiced by the private sale and consequently has no exoneration claim. In Berrington the court held, in a context unrelated to the antideficiency legislation, that the surety's remedy "is not on the original obligation but against the principal upon his implied obligation to reimburse him." ${ }^{68}$ The surety has extinguished the original obligation by paying it, and his section for reimbursement is on an "agreement implied in Iaw." 69

The separate contract theory imposes new duties upon the principal which are not dependent on the primary obligation, ${ }^{70}$ and which survive even though private sale extinguishes the principal's liability to the creditor. According to the language in Berrington, recovery is not on the note or other instrument representing the debt, but is based on the prineipal's implied contractual obligation to make the surety whole. If courts accept the separate contract theory, the section $580 \mathrm{~d}$ defense would not be available to prevent the surety from recovering the amount he has been forced to expend under the suretyship agreement from the principal. Given this result, there is no need to relieve the surety of liability.

The separate contract theory has not gone unchallenged however. ${ }^{71}$ Allowing the surety to recover from the principal after a secured creditor's nonjudicial sale defeats the purpose of section $580 \mathrm{~d} .^{72}$ Upholding a separate agreement for reimbursement between the surety and principal subverts the intent of section $580 \mathrm{~d}$ by preserving the principal's personal liability after nonjudicial sale has defeated his statutory right of redemption. ${ }^{73}$ By recognizing the existence of such a

67. 244 Cal. App. 2d 130, 52 Cal. Rptr. 772 (1966).

68. Id. at 134,52 Cal. Rptr. at 775 .

69. Id. at 135,52 Cal. Rptr. at 776 . "[B] if if an actual agreement between the parties exists, the same would control." Id.

70. Yule v. Bishop, 133 Cal. 574, 579, 62 P. 68, 70 (1901).

71. The court in Union Bank v. Gradsky, 265 A.C.A. 48,71 Cal. Rptr. 64 (1968), expressly disapproves of the Berrington separate contract theory by hoiding that the guarantor's satisfaction of the principal debt does not extinguish the note or the secured character of the transaction for the purposes of the antideficiency legislation. Id. at $53 \& \mathrm{n} .5,71 \mathrm{Cal}$. Rptr. at $68 \& \mathrm{n} .5$. Therefore the guarantor occupies the same position as the creditor and is subject to a section 580d defense when he seeks reimbursement from the principal.

72. Union Bank v. Gradsky, 265 A.C.A. 48, 54, 71 Cal. Rptr. 64, 69 (1968). Hetland asserts that permitting the guarantor to resort to the principal would "obviate the antideficiency legislation." Hetland, supra note 28, at 25.

73. See Union Bank v. Gradsky, 265 A.C.A. 48, 51, 71 Cal. Rptr. 64, 66-67 (1968): “The effect of section $580 \mathrm{~d}$ is to permit deficiency judgments only in those cases in which the creditor, by 
separate agreement, the courts would be permitting the principal to waive, indirectly, the protection afforded by section $580 \mathrm{~d}$, a result which they have heretofor expressly rejected. ${ }^{74}$ If the deficiency prohibition is going to be thus abrogated, it should be by means of a conscious legislative policy, based on close examination of the statute, and reevaluation of its efficacy in terms of present day needs. Defeating the statutory purpose by indirection and subterfuge is clearly undesirable.

\section{Foreclosure of a "Senior" Lien Does Not Prejudice the Surety}

When a creditor who possesses a senior lien forecloses nonjudicially, section 580d does not release the principal from personal liability to the "sold-out" junior creditor. ${ }^{75}$ Therefore, a surety on the junior debt is not barred from seeking reimbursement from the principal and is not exonerated. This analysis explains the following three cases which upheld the surety's liability after nonjudicial sale. In Lange $v$. $A v e r^{76}$ junior creditors sued the endorsers of a promissory note after the property securing the note was sold under a senior deed of trust. Under Roseleaf Corporation v. Chierighino ${ }^{77}$ the senior's nonjudicial foreclosure does not release the principal from liability to the junior; therefore, there is no reason to afford the endorsers antideficiency protection in a suit by sold-out junior lienors. Since the principal is still personally liable, the surety retains his right to reimbursement and has not been prejudiced.

Similarly, in Stephenson v. Lawn ${ }^{78}$ and Engelman v. Gordon ${ }^{79}$ plaintiffs were sold-out junior creditors against whom the principal would not have a defense. The surety should remain liable in these cases

foreclosing judicially, allows the debtor the opportunity of exercising his right of redemption." See note 84 infra for a discussion of the statutory right of redemption.

74. See Freedland v. Greco, 45 Cal. 2d 462, 467, 289 P.2d 463, 465-66 (1965), holding that the antideficiency provisions are nonwaivable. The debtor cannot waive the antideficiency statutes in advance because they were not designed to benefit only those persons directly encompassed within the statutory protection, but to serve the public interest as well. Union Bank v. Gradsky, 265 A.C.A. 48, 52 n.3, 71 Cal. Rptr. 64, 67 n.3 (1968) (citing Freedland, supra); cf. Cal. Civ. CODE $\S 3513$ (West 1954): "Anyone may waive the advantage of a law intended solely for his benefit. But a law established for a public reason cannot be contravened by a private agreement," and American Guar. Corp. v. Stoody, 230 Cal. App. 2d 390, 41 Cal. Rptr. 69 (1964), concluding by implication that a surety can waive a statute whose provisions benefit only himself.

75. Roseleaf Corp. v. Chierighino, 59 Cal. 2d 35, 378 P.2d 97, 27 Cal. Rptr. 873 (1963); see Comstock v. Fiorella, 260 A.C.A. 261, 67 Cal. Rptr. 104 (1968), holding that the "one form of action" provision of CAL. Civ. Pro. Code $\S 726$ (West Supp. 1967) "has no application to a junior lienholder whose security has been exhausted by a sale under the terms of a senior encumbrance." Id. at 266,67 Cal. Rptr. at 107.

76. 241 Cal. App. 2d 793, 50 Cal. Rptr. 847 (1966).

77. 59 Cal. 2d 35, 378 P.2d 97, 27 Cal. Rptr. 873 (1963).

78. 155 Cal. App. 2d 669, 318 P.2d 132 (1957).

79. 242 Cal. App. 2d 510, 51 Cal. Rptr. 627 (1966). 
because he has not lost his right to recover from the principal. ${ }^{80}$ Given this crucial point, the holdings obviously have no bearing on the applicability of the exoneration theory in the proper fact situation-where the creditor to whom the surety has pledged his liability forecloses nonjudicially and defeats the surety's rights against the principal.

THE CONCEPT OF A PROHIBITED DEFICIENCY

\section{A. Allowing Recovery Against the Surety Defeats the Statutory Purpose of Section 580d}

The surety's second major argument is that a judgment against him following the creditor's private sale should be considered a deficiency judgment for the purpose of section $580 \mathrm{~d} .^{81}$ The term "deficiency," as it is normally understood, is not very helpful in determining the surety's liability. From the creditor's viewpoint, the amount remaining due after sale of the security represents a deficiency, irrespective of who has to pay it. One approach to the question of what constitutes a deficiency would be to invoke the prohibition against recovery where it would accomplish a result consonant with the purpose of the statute. Whether a deficiency

80. Hetland, supra note 4 , at 95 .

81. The courts, however, have not held that a surety is entitled to the deficiency protection of section 580d. See, e.g., Engelman v. Gordon, 242 Cal. App. 2d 510, 519,51 Cal. Rptr. 627, 632 (1966) and Lange v. Aver, 241 Cal. App. 2d 793, 798, 50 Cal. Rptr. 847, 850 (1966), both quoting Stephenson v. Lawn, 155 Cal. App. 2d 669, 671, 318 P.2d 132, 134 (1957), "the only person coming within the protective provisions of those sections [580b and 580d] is the principal debtor." Stephenson denied antideficiency protection to the surety on the ground that his was "a separate and distinct obligation and one which can in no way be construed as a deficiency judgment." $I$ d. at 671 , 318 P.2d at 133-34. That rule derived from the earlier cases of Kinsel v. Ballou, 151 Cal. 754, 91 P.620 (1907) and Carver v. Steele, 116 Cal. 116, 47 P.1007, 58 Am. St. Rep. 156 (1897), whose rationale was that "the contract of the endorser is a separate promise from that of the maker of the note, collateral to the original obligation, and is not secured by the mortgage." Lange v. Aver, 241 Cal. App. $2 \mathrm{~d}$ at 800, $50 \mathrm{Cal}$. Rptr. at 851. The outcome in these cases may have been cast in some doubt by the legislative abolition of the distinction between sureties and guarantors, see $\mathrm{CAL}_{\mathrm{AL}}$. CIV. CODE $\S 2787$ (West 1954), at least insofar as denial of protection to the guarantor was based on the separate and independent character of his obligation. See American Guar. Corp. v. Stoody, 230 Cal. App. 2d 390, 393, 41 Cal. Rptr. 69, 71 (1964), citing Everts v. Matteson, 2 I Cal. $2 \mathrm{~d} 437,444,132$ P.2d 476, 481 (1942) for the proposition that the obligation of the principal debtor and that of the guarantor were no longer independent obligations after abolition of the distinction between sureties and guarantors. Guarantors now occupy the same position with respect to the mortgage security as the principal debtor. American Guar. Corp. v. Stoody, supra. Since the character of their obligations is the same, it seems arguable that the guarantor should have the same defense against a deficiency as the principal. The question remains whether the courts will construe Civil Code section 2787 to mean that an action on a guaranty is no longer treated differently from an action on the debt. Hetland queries, "But if abolishing the distinction somehow means that the guarantor is no longer additional security, what is he?" Hetland, supra note 28 , at 27 n.120. 
is barred by section 580d would then turn on an interpretation of legislative intent.

The purpose of section $580 \mathrm{~d}$ was to put nonjudicial enforcement of a deed of trust on a par with judicial foreclosure and sale. ${ }^{82}$ This was accomplished by equalizing the sanctions which judicial and nonjudieial foreclosure offered as alternatives to the creditor. Before enactment of section 580d "it was to the creditor's advantage to exercise a power of sale rather than to foreclose by judicial action." ${ }^{33}$ Creditors preferred private sale because it avoided a statutory period of redemption. ${ }^{84}$ By exercising the power instead of foreclosing judicially, the creditor could obtain a deficiency judgment ${ }^{85}$ as well as the enhanced proceeds of a redemption-free sale. ${ }^{86}$ This procedure allowed the creditor to bid in the property himself at an unfairly low price-or offer that opportunity to someone else-secure in the knowledge that any deficiency would be recoverable in a personal judgment against the principal. ${ }^{87}$ The absence of a redemption right rendered the principal vulnerable to an unrealistically low sales price, ${ }^{88}$ and prevented both him and the surety from protecting themselves by redeeming for the property's true worth. The creditor had an opportunity for a "double recovery" on the debt. ${ }^{89}$

82. Roseleaf Corp. v. Chierighino, 59 Cal. 2d 35, 43, 378 P.2d 97, 102, 27 Cal. Rptr. 873, 878 (1963); Invescal Realty Corp. v. Edgar H. Mueller Constr, Co., 247 Cal. App. 2d 190, 198, 55 Cal. Rptr. 475, 48 I (1966); Hetland, supra note 28, at 30.

83. Roseleaf Corp. v. Chierighino, 59 Cal. 2d 35, 43, 378 P.2d 97, 101-02, 27 Cal. Rptr. 873, 877-78 (1963).

84. Id.; see Hetland, supra note 28, at 29. A statutory period of redemption attaches to judicial sale, Investcal Realty Corp. v. Edgar H. Mueller Constr. Co., 247 Cal. App. 2d 190, 198, 55 Cal. Rptr. 475, 481 (1966), during which time the judgment debtor or redemptioner may redcem the property from the purchaser by paying him the amount of the purchase price plus thc amount of any prior lien held by him as creditor. CAL. Civ. Pro. CoDE $\$ \S 700$, 701 (West 1955); id. $\$ \S 702,703$ (West Supp. 1967).

85. Kass v. Weber, 261 A.C.A. 449, 453, 67 Cal. Rptr. 876, 879 (1968).

86. Because private sale eliminated the possibility of subsequent redemption, the interest acquired at nonjudicial sale was more valuable than that which the creditor could offer in judicial foreclosure.

87. The "fair value" provisions of CAL. Civ. Pro. CODE $\$ \$ 580 a$ (West 1955) and 726 (West Supp. 1967) limited the creditor's recovery to "the amount by which the indebtedness exceeds the fair market value of the property at the time of sale," so long as that amount is not greater than the differcnce between the debt and the actual sale price. Kass v. Weber, 26I A.C.A. 449, 453, 67 Cal. Rptr. 876, 879 (1968).

88. See Roseleaf Corp. v. Chierighino, 59 Cal. 2d 35, 43, 378 P.2d 97, 102, 27 Cal. Rptr. 873, 878 (1963), "The right to redecm, like proscription of a deficiency judgment, has the effect of making the security satisfy a realistic share of the debt;" Salsbery v. Ritter, 48 Cal. 2d I, 11, 306 P.2d 897, 902 (1957), "[O]ne of the primary purposes of statutory redemption is to force the purchaser at the execution sale to bid the property in at a price approximating its fair valuc;" Hetland, supra note 28 , at 30 , "The statutory right of redemption shift [s] the incentive from a low bid to a realistic bid, somewhere close to the fair market value of the security."

89. Under sections $580 \mathrm{a}$ and 726 the creditor was recuuired to show that the fair market value of the property at the time of the sale was less than the debt as a prerequisitc to obtaining a 
He could obtain the property at a bargain price and possibly hold the debtor liable for a "deficiency" lärger than the actual difference between the debt and the true worth of the property.

Section 580d was intended to equalize the advantages of judicial and nonjudicial foreclosure by prohibiting a deficiency judgment after nonjudicial sale..$^{90}$ Where there is no surety, this prohibition forces the creditor to assume the risk of receiving an unreasonably low bid at private sale. The realization that he will receive only the amount of the bid-in view of the statutory denial of recourse to a deficiency-provides the creditor with an incentive to insure the fairness of the sale and the economic reality of the purchase price. ${ }^{91}$ With the creditor bearing the burden of loss, the principal's position is protected; and his need for a redemption right is alleviated.

The situation is clearly altered by the existence of a surety agreement. The curative function of section $580 \mathrm{~d}$ is defeated by denying antideficiency protection to the surety. The creditor can bid in the property for a low price and recover the balance of the debt from the surety in a personal judgment unrestricted by the property's true value.92 As Professor Hetland has observed, "it seems evident that by not reducing his claim to the excess above the property's fair value, the creditor stands to recover more than is owing." ${ }^{\prime 93}$ Permitting such a result destroys the creditor's incentive to insure the fairness of the sale, and to promote maximum liquidation of the debt out of its proceeds. He obtains a double advantage by foreclosing nonjudicially. He can obtain a deficiency from the surety without reference to the property's actual

\footnotetext{
deficiency judgment. However the difficulty involved in making such a showing was substantially ameliorated by the uncertainty involved in proving market value. Hetland asserts that a creditor would have a "reasonable chance" of showing a low market value and obtaining a double recovery. Hetland, supra note 28 , at 29.
}

90. Roseleaf Corp. v. Chierighino, 59 Cal. 2d 35, 43, 378 P.2d 97, I02, 27 Cal. Rptr. 873, 878 (1963).

9I. Although section $580 \mathrm{~d}$ relieves the principal of personal liability for a deficiency, the fairness of the sale price is important to him where he has given "additional security" to the creditor. (See discussion of additional security accompanying notes 105-116 infra).

92. The "fair value" limitations of CAL. CIv. PRo. CODE § 580a (West 1955), which "are designed to prevent creditors from buying in at their own sales at deflated prices and realizing double recoveries by holding debtors for large deficiencies," Roseleaf Corp. v. Chierighino, $59 \mathrm{Cal}$. 2d 35, 40, 378 P.2d 97, 99, 27 Cal. Rptr. 873, 875 (1963), do not apply to limit the creditor's recovery from the surety to the difference between the debt and the property's fair market value. See Bank of America Nat'I Trust \& Sav. Ass'n v. Hunter, 8 Cal. 2d 592, 598, 67 P.2d 99, 102 (1937) (section 580a has no application to an action based on the independent obligation of the guarantor); Security-First Nat'l Bank v. Chapman, 4 l Cal. App. 2d 2I9, 22I-22, 106 P.2d 43I, 432 (I940) (unnecessary for creditor to allege compliance with section 580a in order to state a cause of action against a guarantor); Hetland, supra note 28 , at 27 (referring to the "inapplicability of the fair-value limitations"); $c f$. Everts v. Matteson, 21 CaI. 2d 437, 132 P.2d 476 (I942).

93. Hetland, supra note 28 , at 27. 
value, and no redemption right exists to encourage a realistic price. This inequitable situation clearly parallels that which existed prior to the time the legislature prescribed the preventive medicine of section $580 \mathrm{~d}$ in order to remedy the unfair advantage afforded the creditor as a consequence of his nonjudicial foreclosure.

The principal debtor is entitled to insist on the creditor's compliance with the statutory limitation of alternatives prescribed by section $580 \mathrm{~d}$. The surety should also be able to compel the creditor to an election of remedies. ${ }^{94}$ There is no redemption after nonjudicial sale; in light of the rationale and purpose of section $580 \mathrm{~d}$, denial of the protection embodied in the redemption right should invoke the statutory bar against the surety's personal liability as well as the principal's. Any other outcome would place the surety at the creditor's mercy. Section 580d-unlike $580 \mathrm{~b}$, which "is not directly concerned with the creditor's act of pursuing his remedies by foreclosure or sale" $" 95$-was enacted to apportion more fairly the advantages accruing to the creditor from the foreclosure process. The creditor should not be allowed to frustrate the statutory balancing scheme where the surety benefits from its enforcement. The statutory equalization of the creditor's alternatives should be enforced irrespective of who is thereby protected.96

Under section $580 \mathrm{~b}$, a sale in satisfaction of a purchase money obligation does not relieve the surety of liability, ${ }^{97}$ but this result has no bearing on a determination of the surety's liability under section $580 \mathrm{~d} .^{98}$

94. A comparison of the surety's and the principal's positions supports the conclusion that the surety's claim to antideficiency protection is equally justifiable on equitable grounds. The surcty occupies a more vulnerable position than the principal. His right to cure a default in payment and reinstate the obligation by paying the amount due, under $C_{A L}$. Civ. Code $\S 2924 \mathrm{c}$ (West Supp. 1968) is questionable at best. That statute limits the right to reinstate to the trustor or mortgagor or his successor in interest, and to a beneficiary under a subordinate deed of trust or any other person having a subordinate lien or encumbrance on the property. The surety may be unable to protect himself in the event of a default, while the principal would be able to take advantage of his right of reinstatement during the three month period following recordation of the default notice, and thereby avoid foreclosure. Smith v. Allen, 68 A.C. 91, 94, 436 P.2d 65, 67, 65 Cal. Rptr. 153, 155 (1968). C. Hetland, supra note 28, at 36 n.162: "Cal. Civ. Code $\$ 2924 \mathrm{c}$ relieves the debtor cven from express acceleration, allowing him to rcinstate by payment of nonaccelerated arrearages."

95. Younker v. Reseda Manor, 255 Cal. App. 2d 431, 435, 63 Cal. Rptr. 197, 200 (1967).

96. Once the courts hold that the antideficiency prohibition of section $580 \mathrm{~d}$ encompasses the surety, he will not be able to waive the protection of that statute, as Union Bank v. Gradsky suggests. 265 A.C.A. 48, 56, 71 Cal. Rptr. 64, 70 (1968), supra note 58. See Freedland v. Greco, 45 Cal. 2d 462, 289 P.2d 463 (1965) and other authorities cited note 74 supra on the invalidity of the waiver.

97. Heckes v. Sapp, 229 Cal. App. 2d 549, 40 Cal. Rptr. 485 (1964); Katz v. Haskell, 196 Cal. App. 2d 144, 16 Cal. Rptr. 453 (1961); Stephenson v. Lawn, 155 Cal. App. 2d 669, 318 P.2d 132 (1957) (latter two cases imposed personal liability on vendors who endorsed and assigned secured notes received as part of the purchase price of property); Hetland, supra note 28, at 27-28.

98. "[T]he cases interpreting section 580b of the Code of Civil Proccdure are of limitcd use in deciding a case under section $580 \mathrm{~d}$ because the lcgislative purposes were not identical in enacting the 
His continued liability in the purchase money situation governed by section $580 \mathrm{~b}$ derives from the fact that the statutory purpose does not require his release. ${ }^{99}$ Section $580 \mathrm{~b}$ was intended to protect the purchaser of property by preventing "the aggravation of the downturn that would result if defaulting purchasers were burdened with large personal liability during depression periods." relieving the purchaser of personal liability to the seller or purchase money lender who takes a security interest in the property purchased. ${ }^{101}$ Since section $580 \mathrm{~b}$ was intended to serve as a depression cushion for the benefit of defaulting purchasers, ${ }^{102}$ excluding the surety from its scope does not defeat its purpose. Section 580b's definition of a deficiency as "a personal judgment on the debt against the debtor" ${ }^{103}$ derives from the statute's purchaser-protection purpose, without which the definition fails. ${ }^{104}$ Once a statute turns from preoccupation with protecting the purchaser to remedying the creditor's unfair advantage, it is no longer necessary to exclude the surety from its scope merely because his is not the purchaser's liability.

\section{B. Additional Security or Prohibited Deficiency?}

The California supreme court has held that the deficiency prohibition of section $580 \mathrm{~d}$ does not prevent the creditor from foreclosing on "additional security." consequently turns on whether his obligation falls into the category of permissible "additional security" or prohibited deficiency. ${ }^{106}$ It is

two sections. . . " Union Bank v. Gradsky, 265 A.C.A. 48, 55-56, 71 Cal. Rptr. 64, 69-70 (1968).

99. See, e.g., Heckes v. Sapp, 229 Cal. App. 2d 549, 553, 40 Cal. Rptr. 485, 487-88 (1964): "[T]he guarantor's obligation is not a variation of the standard purchase money mortgage transaction within the purposes of section $580 \mathrm{~b}$, and the guarantor should not be protected against a deficiency judgment."

100. Roseleaf Corp. v. Chierighino, 59 Cal. 2d 35, 42, 378 P.2d 97, 101, 27 Cal. Rptr. 873, 877 (1963); see Bargioni v. Hill, 59 Cal. 2d 121, 123, 378 P.2d 593, 594, 28 Cal. Rptr. 321, 322 (1963).

101. Bargioni v. Hill, 59 Cal. 2d 121, 123, 378 P.2d 593, 594, 28 Cal. Rptr. 321, 322 (1963).

102. Hetland, supra note 28 , at 5 .

103. Id. at $31 \mathrm{n} .143$.

104. See id. at 32 n.143: "The reason underlying the ...580b deficiency definition ... does not cxist where the transaction was not a purchase money transaction. Absent the reason for the ... definition, the definition has no validity."

105. Freedland v. Greco, 45 Cal. 2d 462, 466, 289 P.2d 463, 465 (1955) (creditor may exhaust additional security after sale under the power in a trust deed without regard to the "fair value" limitation of section 580a); Hatch v. Security-First Nat'l Bank, 19 Cal. 2d 254, 260, 120 P.2d 869, 873 (1942).

106. Discussing the applicability of section 580 a to a guarantor, the California supreme court in Bank of America Nat'l Trust \& Sav. Ass'n v. Hunter, 8 Cal. 2d 592, 67 P.2d 99 (1937) distinguished an action on a guaranty from an action for recovery of a deficiency judgment. However Hunter does not compel the conclusion that a surety agreement would constitute 
submitted that the term "additional security" is not dispositive. Anything the creditor receives from the principal in addition to his promise to repay could be characterized as additional security, including a suretyship agrcement. The real issue is whether it would frustrate the objectives of the statute to allow the creditor to recover a personal money judgment from the surety. If it would, the courts should regard the surety's obligation as a prohibited deficiency, rather than additional security.

In the context of a purchase money obligation governed by section 580b, Heckes $v$. Sapp ${ }^{107}$ allowed recovery against the guarantor on the ground that "[a] guaranty is simply additional security for the obligor's debt." 108 This holding appears correct in view of the objectives of section $580 \mathrm{~b}$ discussed above. ${ }^{109}$ lts legislative purpose was to provide purchase money antideficiency protection for the purchaser; section $580 \mathrm{~b}$ was not designed to deal with the liability of anyone else. Thus, the only recovery which constitutes a barred deficiency in terms of the policy underlying section $580 \mathrm{~b}$ is recovery from the principal debtor.

The California supreme court concluded in Freedland $v$. Greco ${ }^{110}$ that allowing a creditor who forecloses nonjudicially to resort to property comprising "additional security" does not defeat the purpose of section 580d. The security consisted of a trust deed on real property and a chattel mortgage on certain equipment, the mortgage being the additional security in issue. That security was of a manifestly different character than a suretyship obligation. A creditor who seeks recovery from a surety after nonjudicial foreclosure is not merely exhausting additional security in the form of property or other tangibles, but is attempting to hold another personally liable for a specified monetary amount." That distinction is especially meaningful in view of the equalizing purpose of section 580d. In order to put "judicial enforcement on a parity with private enforcement,"112 the statute provides the creditor

"additional security" under section 580d. Hunter was decided before enactment of section $580 \mathrm{~d}$ and therefore cannot purport to determine the surety's position with respect to that statute. Because of section 580d's equalizing purpose, the surety's position with respect to section 580a need not dictate his position under section $580 \mathrm{~d}$.

107. 229 Cal. App. 2d 549, 40 Cal. Rptr. 485 (1964).

108. Id. at 553, 40 Cal. Rptr. at 488 .

109. See text accompanying notes 100-04 supra.

110. 45 Cal. 2 d 462, 289 P.2d 463 (1955).

111. The California supreme court in Hatch v. Security-First Nat'l Bank, 19 Cal. 2d 254, 120 P.2d 869 (1942) states that "where the creditor seeks a personal judgment for the unpaid balance due upon an obligation after unsuecessful resort to the security" the aetion is one for a deficiency. "The action thus characterized has long been described in this state as an action to obtain a deficiency judgment." Id. at 261, 120 P.2d at 873.

112. See note 82 and accompanying text supra. 
with a choice between retaining another's personal liability and securing title free of any statutory redemption right. ${ }^{113}$ Allowing recovery against a surety in the context of section 580d subverts the purpose of the statute by enabling the creditor to obtain another's personal liability in addition to nonredeemable title. In contrast, permitting the creditor to resort to additional property security does not so offend the statutory scheme. ${ }^{114}$ Real property and chattel security do not afford the creditor the advantages of a personal money obligation. ${ }^{115}$ The value of an interest in real or other property is uncertain as contrasted with a personal judgment against a solvent surety. A personal judgment against a reputable person or business firm carries with it a moral compulsion that a property interest lacks. A creditor possessing a personal judgment obtains a powerful sanction against the judgment debtor in terms of the pressure such a judgment exerts within the business community. In contrast, the creditor who resorts to property can only rely on his own business acumen and fluctuating property values for satisfaction of the debt. He may not possess sufficient knowledge to accurately assess property values. He may have to rely on his own bid at sale if the other bids are unacceptably low and do not justify losing the property. If the creditor is forced to purchase the property at the sale he cancels the debt to the extent of his bid and consequently relinquishes cash payment. He is left with possibly indisposable property, and at the mercy of market fluctuations, when he may be in need of liquid assets. In sum, where additional real or personal property security is involved, the creditor does not enjoy the advantages of a personal judgment after private sale. Allowing the creditor to pursue property security does not enable him to thwart the statute by combining the benefits of judicial and nonjudicial foreclosure. The courts' approach toward real or personal property should not be construed as authority for allowing the creditor to resort to the personal liability represented by a suretyship obligation.

The most compelling reason why the concept of additional security

113. See Roseleaf Corp. v. Chierighino, 59 Cal. 2d 35, 43-44, 378 P.2d 97, 102, 27 Cal. Rptr. 873,878 (1963): "If the creditor wishes a deficiency judgment, his sale is subject to statutory redemption rights. If he wishes a sale resulting in nonredecmable title, he must forego the right to a deficiency judgment."

114. The assignment of rentals which Mortgage Guar. Co. v. Sampsell, 51 Cal. App. $2 d 180$, 124 P.2d 353 (1942), decmed additional security is comparable to additional property security in that such rentals do not afford the creditor the same recovery as a personal money judgment. The rentals are limited to a predetermined amount, and derive from the property rather than obligating the principal personally.

115. Hetland recognizes a distinction in his suggestion that, (by allowing recourse to the surety in the purchase money situation), "[p]ossibly the legislature has chosen to leave available a method for the lender to reasonably assure himself that he will be satisfied in cash rather than property." Hetland, supra note 28 , at 28. 
should not be extended to include a personal money judgment from the surety is that it would subvert the equalizing purpose of section $580 \mathrm{~d}$. As the California supreme court has implemented the concept of additional security with respect to the principal, the creditor can resort to additional security after nonjudicial sale without first having to comply with section 580a of the California Code of Civil Procedure and obtain a judicial determination of the actual deficit remaining on the debt. ${ }^{116}$ This means that no "fair value" limitation applies to restrict the creditor's recovery after nonjudicial sale. The creditor can continue to exhaust additional security regardless of the actual value of the property sold so long as the proceeds from prior sales do not satisfy the debt. This juclicial position clearly weights nonjudicial sale in the creditor's favor and unfairly jeopardizes the principal's interests. A judicial determination that a surety's obligation also constitutes additional security under section 580d would magnify the unfair advantage to the creditor. ${ }^{117} \mathrm{~A}$ creditor with foresight and some acquaintance with the law would demand a surety bond as well as additional property security and thereby insure himself a succession of recoveries. Permitting the creditor this kind of windfall promotes depressed sales prices since it is in his interest to preserve as much of the outstanding debt as possible. The assurance of an ultimate personal judgment encourages the creditor to purchase the property for a cleflated price at his own sale, unless someone else overbicls him. He then stands to recover a money judgment from the surety which is far in excess of the actual amount remaining due, in terms of the true value of the property he has acquired or disposed of.

\section{CONCLUSION}

The surety should be entitled to antideficiency protection under section 580d, and not merely afforded a waivable exoneration defense as in Union Bank v. Gradsky.!! Although Gradsky broke ground by recognizing the indirect implications of the antideficiency legislation for the surety, the court expressly refrained from affording the surety a

116. See Freedland v. Greco, 45 Cal. 2d 462, 289 P.2d 463 (1965); Hatch v. Security-F̈irst Nat'l Bank, 19 Cal. 2d 254, 120 P.2d 869 (1942); Bank of America Nat'l Trust \& Sav. Ass'n v. Hunter, 8 Cal. 2d 592, 67 P.2d 99 (1937).

117. It might be suggested that the unfairness of construing the surety's obligation as additional security could be remedied by applying the section $580 \mathrm{a}$ fair value limitations to the creditor when he seeks recovery from the surety. However this would be only a partial solution. It would place the burden on the surety of convincing a court that the property was sold for less than its fair market value. This is a particularly difficult showing to make since the court usually relies on the actual sale price as an indication of market value. The unfairness to the surety is compounded by the fact that the creditor conducted the sale; as an interested party he should bear the burden of showing the reasonableness of the sale price.

118. 265 A.C.A. 48, 71 Cal. Rptr. 64 (1968). 
direct nonwaivable statutory defense. The statutory purpose of section $580 \mathrm{~d}$ requires that the surety be encompassed within its protection. Section 580d's equalizing role would be defeated if the creditor could obtain the advantage of nonredeemable private sale and at the same time be able to hold the surety personally liable for a deficiency. The inequities of the present untenable judicial position respecting additional security should not be extended to sureties. The creditor should be regarded as seeking a deficiency prohibited by section $580 \mathrm{~d}$ rather than merely exhausting additional security when he attempts to resort to the surety following private sale. A creditor who elects to enforce his lien out of court should thereafter be barred from seeking the benefits associated with judicial enforcement by means of a personal judgment.

Ellen Jacqueline Beilock 